\title{
BIOLEACHING NIKEL DARI BIJIH LIMONIT PULAU GAG MENGGUNAKAN BAKTERI MIXOTROF
}

\author{
Bioleaching of Nickel from Limonite Ore of Gag Island Using Mixotrophic \\ Bacteria
}

\section{ZAKI MUBAROK ${ }^{1}$, BETRI E. PRATAMA ${ }^{2}$ dan SITI K. CHAERUN ${ }^{3}$}

1 Program Studi Teknik Metalurgi, Institut Teknologi Bandung

Jl. Ganesha 10, Bandung 40132, Jawa Barat, Indonesia

2 PT. Antam, Tbk., Unit Bisnis Penambangan Emas, Pongkor

Desa Bantarkaret PO BOX 1, Nanggung 16650 Bogor

3 Sekolah Ilmu dan Teknologi Hayati, Institut Teknologi Bandung

Jl. Ganesha 10, Bandung 40132, Jawa Barat, Indonesia

Email: zaki@mining.itb.ac.id

\begin{abstract}
ABSTRAK
Bioleaching merupakan alternatif proses yang saat ini terus dikembangkan untuk ekstraksi bijih nikel laterit, generasi reagen pelindi dibantu oleh mikroorganisme yang dikembangbiakkan melalui bioteknologi yang murah dan ramah lingkungan. Paper ini menyajikan hasil-hasil percobaan bioleaching bijih nikel laterit tipe limonit dari Pulau Gag dengan bantuan bakteri mixotrof, yaitu jenis bakteri yang dapat hidup baik dari bahan organik maupun bahan kimia anorganik. Bakteri mixotrof yang digunakan adalah Alicyclobacillus ferrooxidans, Bacillus mucilaginosus dan Pseudomonas putida yang diisolasi dari daerah penambangan nikel di Soroako, Sulawesi Selatan. Serangkaian percobaan bioleaching menggunakan rotating shaker telah dilakukan untuk mempelajari pengaruh jenis substrat organik (molase dan air lindi dari tempat pembuangan akhir sampah Leuwigajah, Jawa Barat), penambahan belerang $(10,20,30 \% \mathrm{w} / \mathrm{w}$ ) dan distribusi ukuran partikel bijih $(-60+80 \#,-100+200 \#$ dan -200\#) terhadap persen ekstraksi nikel dan perubahan pH larutan selama pelindian. Hasil penelitian menunjukkan persen ekstraksi $\mathrm{Ni}$ tertinggi sebesar $34,3 \%$ diperoleh dari percobaan bioleaching menggunakan substrat organik air lindi dan distribusi ukuran partikel bijih $-60+80$ mesh, serta penambahan belerang sebanyak 20\% berat setelah proses berlangsung 28 hari. Pada kondisi ini, persen Fe dan Mg terlarut masing-masing sebesar $1,15 \% \%$ dan $6,8 \%$ yang mengindikasikan selektivitas bioelaching cukup baik terhadap besi dan magnesium. Hasil analisis larutan menunjukkan terbentuknya asam sulfat dalam larutan hasil oksidasi belerang yang dikatalisasi oleh bakteri. Persen ekstraksi Ni masih mungkin ditingkatkan diindikasikan oleh nilai pH yang cenderung masih turun sesudah 28 hari.
\end{abstract}

Kata kunci: Bioleaching, nikel, laterit, ekstraksi, bakteri mixotrop

\begin{abstract}
Bioleaching is an alternative method that is currently being developed for nickel laterite extraction, in which the leaching agent is generated by microorganisms prepared by cheap and environmentally friendly biotechnology. In the present paper, the results of bioleaching tests of limonitic nickel laterite ore from Gag Island with the assistance of mixotrophic bacteria (i.e. the bacteria that can grow either in organic and inorganic chemical nutrient sources) are presented. The mixotropic bacteria used were Alicyclobacillus ferrooxidans, Bacillus mucilaginosus and Pseudomonas putida, which were isolated from nickel mining area in Soroako, South Sulawesi Province of Indonesia. Series of bioleaching assays by using rotating shaker were carried out to study the effects of organic substrate (i.e. molasse and leachate from the final waste disposal site of Leuwigajah in West Java), addition of elemental sulfur $(10,20,30 \% \mathrm{w} / \mathrm{w})$ and ore particle size distribution $(-60+80 \#,-100+200 \#$ dan -200\#) on nickel extraction percentage and solution pH alteration during leaching. The investigation results demonstrate that the highest Ni extraction of $34.3 \%$ is obtained from the bioleaching assay of the ore with particle size distribution of $-60+80$ mesh, using the leachate as organic substrate and by the
\end{abstract}


addition of $20 \mathrm{wt} \%$ of sulfur after 28 days. Under this experimental condition, the dissolved Fe and $\mathrm{Mg}$ are $1.15 \%$ and $6.8 \%$, respectively, which indicates a good leaching selectivity to iron and magnesium. Solution analysis result indicates the formation of sulphuric acid in the leach solution is catalyzed by the bacteria. Nickel extraction tends to be improveable, indicated by the tendence of lowering $\mathrm{pH}$ beyond 28 days of leaching.

Keyword: Bioleaching, nickel, laterite, extraction, mixotrophic bacteria

\section{PENDAHULUAN}

Hingga saat ini, pengolahan bijih nikel laterit di Indonesia lebih banyak dilakukan pada bijih yang berkadar tinggi yang dilakukan melalui jalur pirometalurgi, yaitu untuk menghasilkan feronikel dan nikel matte. Sementara, lapisan dengan kadar nikel yang lebih rendah yaitu lapisan limonit sampai saat ini belum banyak diolah, meskipun jumlahnya melimpah. Proses ekstraksi nikel laterit berkadar rendah di industri umumnya dilakukan dengan jalur hidrometalurgi (Dalvi dkk., 2004). Proses-proses hidrometalurgi yang telah dikembangkan serta diterapkan di industri meliputi Proses Caron, PAL/ HPAL (Pressure/High Pressure Acid Leaching), AL (Atmospheric Agitation Leaching) dan HL (Heap Leaching). Salah satu komponen utama biaya operasi pabrik-pabrik hidrometalurgi tersebut adalah konsumsi reagen pelindi. Semakin tinggi konsumsi reagen pelindi dalam suatu pabrik pengolahan, misalnya konsumsi asam sulfat, maka pabrik tersebut menjadi kurang kompetitif. Selain itu, proses-proses tersebut di atas memerlukan penanganan limbah yang ketat yang dihasilkan setelah proses pelindian. Oleh karena itu, diperlukan metode-metode dan teknologi alternatif untuk mengatasi permasalahanpermasalahan tersebut di atas. Salah satu metode alternatif untuk ekstraksi nikel dari bijih nikel laterit yang saat ini sedang menjadi perhatian para peneliti dunia adalah bioleaching (Tang dkk., 2006).

Bioleaching adalah proses pelindian untuk melarutkan logam dari mineralnya dengan bantuan aktivitas mikroorganisme. Sama halnya dengan proses pelindian pada umumnya, prinsip proses pelindian menggunakan mikroorganisme adalah melakukan pelarutan selektif unsur/logam dari mineral tertentu. Asam yang dimanfaatkan sebagai reagen pelindi merupakan hasil metabolisme mikroorganisme.

Proses bioleaching diperkirakan lebih kompetitif dibanding proses chemical leaching karena mikroorganisme yang digunakan dalam prosesnya dapat diregenerasi dengan murah. Beberapa jenis bakteri mudah untuk dikembangbiakkan dengan bioteknologi yang telah berkembang saat ini. Dalam proses ini tidak diperlukan asam sulfat atau asam anorganik lainnya sehingga tidak diperlukan pendirian pabrik asam (acid plant) yang konsekuensinya akan menurunkan biaya modal dan biaya operasi pabrik asam ini. Dari sisi lingkungan, bioleaching dikenal lebih ramah lingkungan karena karakteristik limbahnya yang bersifat organik dan kuantitasnya cenderung sedikit (Jain and Sharma 2004).

Salah satu faktor yang memengaruhi pertumbuhan bakteri yang berguna dalam proses bioleaching adalah jenis substrat organik yang berfungsi sebagai sumber energi bagi pertumbuhan bakteri tersebut. Substrat ini memiliki peranan penting dalam menyediakan unsur-unsur tertentu untuk pertumbuhan sel-sel bakteri. Untuk mampu tumbuh dan beraktivitas, sel-sel mikroorganisme memerlukan unsur-unsur seperti karbon, oksigen, hidrogen, nitrogen, fosfor, belerang dan magnesium dalam jumlah tertentu (Jain and Sharma 2004, Simate, 2009). Substrat organik ini umumnya dimasukkan ke dalam suatu media pertumbuhan dari mikroorganisme. Oleh karena itu, media yang digunakan harus mendukung tersedianya nutrisi bagi pertumbuhan mikroorganisme tersebut.

Berdasarkan sumber nutrisi utamanya, diketahui terdapat jenis bakteri kemolitotrof, heterotrof dan belakangan ini dikenal pula tipe bakteri mixotrof. Bakteri kemolitotrof tertentu membutuhkan sumber nutrisi anorganik tertentu pula. Sebagai contoh, Acidithiobacillus ferrooxidans memanfaatkan $\mathrm{Fe}(\mathrm{II})$ sebagai sumber nutrisi dan sumber energi. Bakteri Sulfobacillus thermosulfidooxidans sangat bergantung kepada belerang yang terkandung dalam media. Bakteri mixotrof diketahui memiliki kemampuan dalam memanfaatkan sumber nutrisi anorganik dan juga organik seperti karbon (Alting, 2010 dan Sutina, 2010). Keberadaan bakteri tipe mixotrof yang beberapa strain-nya digunakan untuk penelitian ini telah dikonfirmasi oleh Alting dan Sutina (Alting, 2010 dan Sutina, 2010).

Penelitian bioleaching bijih nikel laterit telah dilakukan melalui berbagai perlakuan dan variasi, namun masih belum mencapai hasil yang optimal. Penelitian bacterial leaching sebelumnya kebanyakan menggunakan mikroorganisme yang bersifat 
heterotrof, yaitu mikroorganisme yang memperoleh energi dengan mengkonsumsi bahan organik, dan kemolitotrof, yaitu mikroorganisme yang memanfaatkan besi dan belerang untuk hidup (Simate, 2009). Masih sangat sedikit penelitian yang menggunakan bakteri mixotrof yaitu jenis bakteri yang dapat hidup baik dari bahan organik maupun bahan kimia. Oleh karena itu, penggunaan bakteri yang media hidupnya lebih fleksibel dan murah untuk pelindian bijih nikel laterit masih perlu diteliti dan dipelajari unjuk kerjanya.

\section{METODE}

\section{Percontoh Bijih Nikel Laterit}

Percontoh bijih nikel laterit yang digunakan pada penelitian ini diperoleh dari PT ANTAM Tbk. yang berasal dari Pulau Gag. Bijih digerus dan kemudian diayak untuk mendapatkan distribusi ukuran +60 mesh, $-60+80$ mesh, $-100+200$ mesh, dan -200 mesh.

Pemilihan distribusi ukuran bijih ini merujuk pada percobaan bioleaching menggunakan konsorsium jamur yang sebelumnya telah dilakukan oleh Astuti,
2011. Karakterisasi percontoh bijih meliputi analisis komposisi kimia dengan XRF dan analisis mineral yang dominan dalam bijih dengan XRD. Hasil analisis komposisi kimia bijih dengan XRF ditunjukkan pada Tabel 1. Hasil analisis XRD percontoh bijih ditunjukkan pada Gambar 1. Hasil analisis XRD menunjukkan bahwa mineral-mineral yang dominan pada bijih ialah enstatite $(\mathrm{Mg}, \mathrm{Fe}) \mathrm{SiO}_{3}$, goethite $(\mathrm{FeOOH})$, gibbsite $\left(\mathrm{Al}(\mathrm{OH})_{3}\right)$ dan nickel silicate hydroxide $\left(\mathrm{Ni}_{3} \mathrm{Si}_{4} \mathrm{O}_{10}(\mathrm{OH})_{2}\right)$.

Tabel 1. Hasil analisis komposisi kimia percontoh bijih nikel limonit dari Pulau Gag yang digunakan dalam penelitian

\begin{tabular}{cc}
\hline Senyawa/Unsur & $\%$ Berat \\
\hline $\mathrm{Ni}$ & 1,59 \\
$\mathrm{Fe}$ & 40,10 \\
$\mathrm{MgO}$ & 2,18 \\
$\mathrm{SiO}_{2}$ & 10,04 \\
$\mathrm{Co}$ & 0,09 \\
$\mathrm{CaO}$ & 0,57 \\
$\mathrm{Fe} / \mathrm{Ni}$ & 25,38 \\
\hline
\end{tabular}

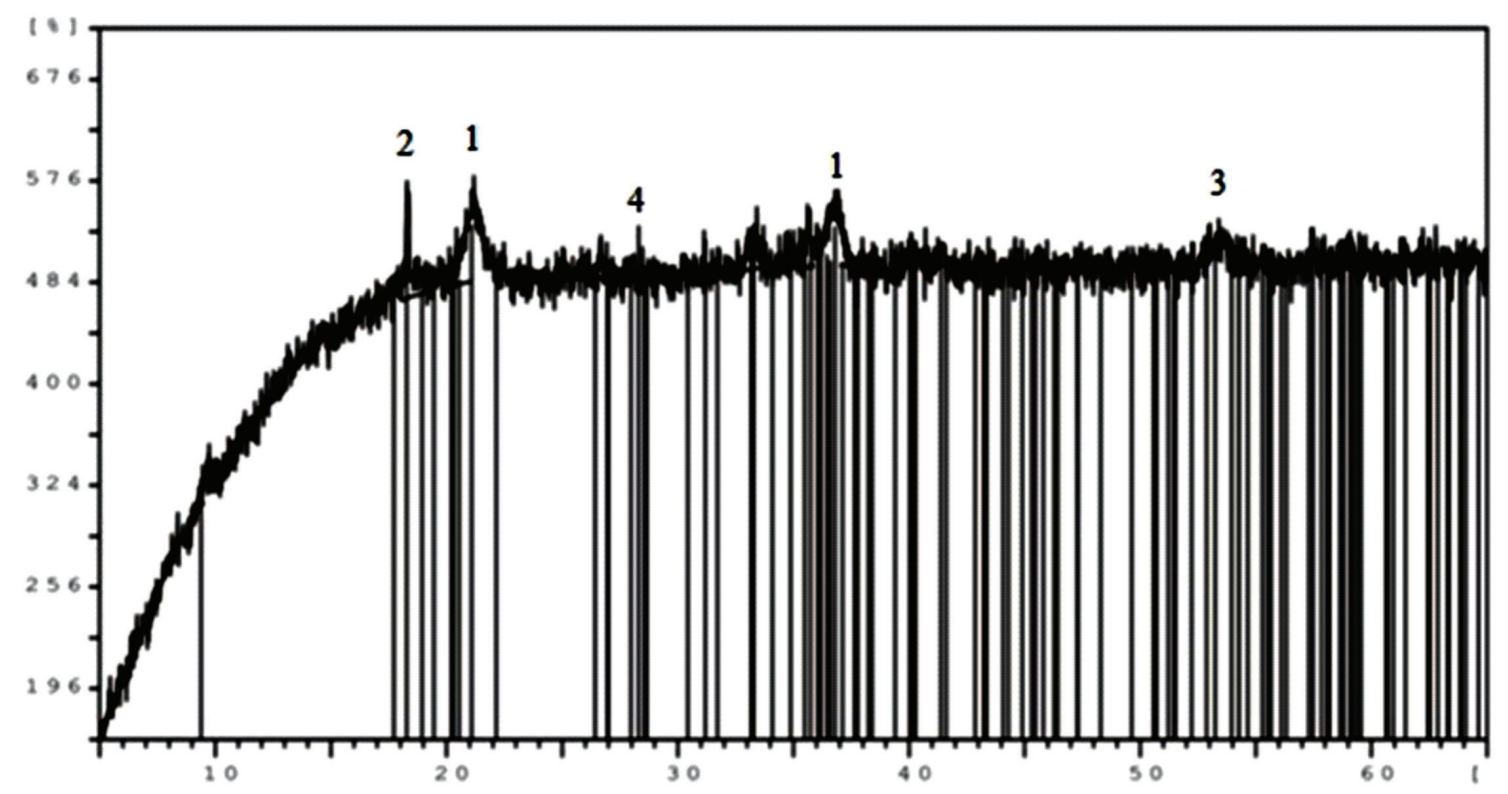

\section{Goethite (FeOOH) \\ 2. Gibbsite $\left(\mathrm{Al}(\mathrm{OH})_{3}\right)$ \\ 3. Enstatite $(\mathrm{Mg}, \mathrm{Fe}) \mathrm{SiO}_{3}$ \\ 4. Nickel-hydroxi-silicate $\left(\mathrm{Ni}_{3} \mathrm{Si}_{4} \mathrm{O}_{10}(\mathrm{OH})_{2}\right)$}

Gambar 1. Hasil analisis XRD percontoh bijih 


\section{Bakteri}

Konsorsium bakteri yang digunakan terdiri dari Alicyclobacillus ferrooxidans, Bacillus mucilaginosus dan Pseudomonas putida. Bakteri-bakteri ini ditumbuhkan dalam medium Fe-broth, baik pada saat pengkulturan maupun sebagai media pada saat percobaan pelindian, yang memiliki komposisi sebagai berikut (gram/liter): $\left(\mathrm{NH}_{4}\right) \mathrm{SO}_{4}$, 0,5; $\mathrm{NaNO}_{3}, 0,5 ; \mathrm{K}_{2} \mathrm{HPO}_{4}, 0,5 ; \mathrm{MgSO}_{4} .7 \mathrm{H}_{2} \mathrm{O}, 0,5$; $\mathrm{FeSO}_{4} .7 \mathrm{H}_{2} \mathrm{O}, 5,9 ;$ Triptone, 1.

\section{Sumber Substrat Organik}

Bakteri yang digunakan mendapatkan sumber energi dari karbon (C) organik dan substrat kimia (bubuk belerang). Molase dan air lindi (yang diambil dari tempat pembuangan akhir sampah di Leuwigajah, Kabupaten Bandung Barat) dimanfaatkan sebagai sumber karbon organik sekaligus sebagai sumber energi bagi bakteri. Ketiga spesies bakteri diperoleh dari hasil isolasi yang dilakukan oleh peneliti sebelumnya yang berhasil mengisolasi bakteri-bakteri Alicyclobacillus ferrooxidans, Bacillus mucilaginosus dan Pseudomonas putida dari pertambangan nikel di Soroako, Sulawesi Tenggara (Alting, 2010 dan Sutina, 2010).

\section{Percobaan dan Analisis}

Percobaan dilakukan menggunakan medium Febroth, 5\% w/v (berat bijih/volume larutan) dengan volume larutan $150 \mathrm{ml}$ dan $5 \%$ v/v sumber karbon organik. Percobaan dilakukan di dalam sebuah rotating shaker dengan kecepatan putaran 180 rpm pada suhu kamar dengan perbandingan 1:1:1 untuk setiap 3 jenis bakteri berjumlah 106 CFU/ml inokulum. Jumlah sel bakteri ini merupakan sel hidup dengan satuan CFU/ml (colony-forming units per milliliter) yang ditentukan dengan menggunakan metode pengenceran dan TPC (total plate count) serta inokulasi bakteri menggunakan metode plating tuang. Metode ini dapat menghitung secara langsung jumlah bakteri yang hidup dan juga dapat memonitor pertumbuhan bakteri tersebut (Madigan dkk., 2010).

Percobaan bioleaching dilakukan dengan variasi distribusi ukuran bijih nikel, yaitu $-60+80$ mesh, $-100+200$ mesh dan -200 mesh, variasi jumlah sumber C organik (molase dan air lindi) serta jumlah belerang yang ditambahkan $(10 \%$ berat belerang per berat bijih (w/w) , 20\% w/w, dan $30 \% \mathrm{w} / \mathrm{w})$.

Percontoh larutan hasil lindian diambil pada rentang waktu setiap tujuh hari selama 28 hari. Kon- sentrasi nikel dan besi yang terlarut diukur dengan AAS yang dilakukan secara duplo untuk setiap percontoh. Nilai $\mathrm{pH}$ larutan sebagai fungsi waktu diukur dengan $\mathrm{pH}$-meter. Untuk melihat pengaruh penambahan belerang, dilakukan analisis kadar sulfat dengan cara titrasi menggunakan larutan $\mathrm{NaOH}$ dengan konsentrasi $1 \mathrm{~N}$. Residu pelindian pada setiap variasi percobaan dikeringkan untuk dianalisis dengan cara XRD. Percontoh yang diambil adalah percontoh dengan persen ekstraksi $\mathrm{Ni}$ terendah untuk dilihat komposisi mineralnya. Percontoh residu ini diambil setelah pelindian selesai (setelah 28 hari).

\section{HASIL DAN PEMBAHASAN}

\section{Pengaruh Jenis Substrat}

Profil perubahan $\mathrm{pH}$ sebagai fungsi waktu pada 2 jenis substrat dan distribusi ukuran bijih $-60+80$ mesh untuk penambahan $10 \%, 20 \%$ dan $30 \%$ (w/w) belerang ditunjukkan pada Gambar 2a-c.

Hasil penelitian menunjukkan telah terjadi penurunan $\mathrm{pH}$ dengan berjalannya waktu, yang mengindikasikan berlangsungnya pembentukan asam oleh aktivitas bakteri. Perbedaan $\mathrm{pH}$ awal larutan disebabkan oleh perbedaan $\mathrm{pH}$ dari molase dan air lindi. Hasil pengukuran menunjukkan pada kondisi awal air lindi mempunyai nilai pH 8,4 dan molase mempunyai $\mathrm{pH}$ awal 3,4. Penambahan 5\% (v/v) sumber karbon organik terhadap volume larutan menyebabkan perubahan $\mathrm{pH}$ awal larutan. Untuk media Fe-broth yang dicampur dengan air lindi, $\mathrm{pH}$ awal larutan yang terukur adalah 4,9. Media Fe-broth yang dicampur dengan molase menghasilkan suasana yang lebih asam dengan nilai $\mathrm{pH}$ awal terukur 4 .

Dari hasil pengukuran $\mathrm{pH}$ terlihat bahwa substrat air lindi lebih efektif bagi aktivitas bakteri Alicyclobacillus ferrooxidans, Bacillus mucilaginosus dan Pseudomonas putida yang menghasilkan asam untuk proses pelindian nikel. Penurunan $\mathrm{pH}$ yang tajam yang teramati pada minggu pertama mengindikasikan bahwa air lindi merupakan substrat yang lebih cocok untuk bakteri-bakteri tersebut.

Penurunan $\mathrm{pH}$ yang signifikan terjadi karena air lindi mengandung nutrisi yang dibutuhkan oleh bakteri dalam jumlah yang sesuai. Bakteri membutuhkan nutrisi, baik dalam jumlah banyak (major nutrient) maupun dalam jumlah sedikit (minor nutrient). Sesuai dengan karakternya, bakteri mixotrof membutuhkan substrat karbon organik dan substrat 

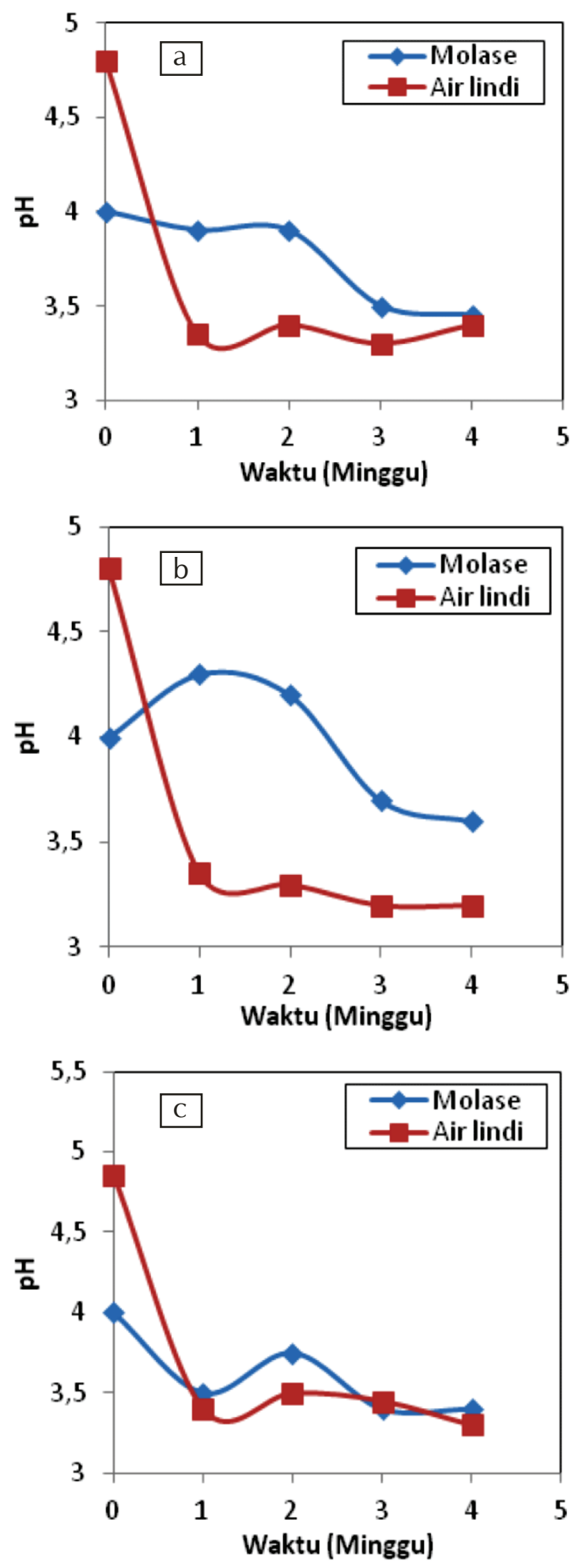

Gambar 2. Profil perubahan pH terhadap waktu pada variasi jenis substrat organik, untuk bijih dengan fraksi ukuran -60+80 mesh dan penambahan (a) $10 \% \mathrm{~S}$ (b) $20 \% \mathrm{~S}$ (c) $30 \% \mathrm{~S}$ anorganik sebagai sumber energinya. Jumlah karbon organik, sebagai nutrisi utama harus sesuai dan tidak boleh berlebihan.

Jumlah nutrisi yang berlebihan akan memberikan efek negatif yang menyebabkan bakteri menjadi kurang aktif. Molase mengandung karbon organik yang jauh lebih banyak dibandingkan air lindi. Ratarata sebanyak $60 \%$ karbon organik terkandung per 100 gram padatan molase (Olbrich, 2006). Jumlah ini jauh lebih tinggi dibandingkan dengan kandungan karbon organik pada percontoh air lindi yang diambil dari tempat pembuangan sampah akhir di daerah Leuwigajah, untuk penelitian ini sebesar 968 ppm total karbon organik (Robinson, 2007).

Faktor lain yang diamati adalah nutrisi minor yang terkandung dalam kedua jenis substrat. Air lindi (leachate) yang diambil dari TPA sampah Leuwigajah seperti ditunjukkan pada Tabel 2 (Setiyanto dkk., 2012) lebih banyak mengandung elemen-elemen atau nutrisi-nutrisi yang dapat mempercepat proses pertumbuhan bakteri. Dalam penelitian ini, bakteri yang digunakan tidak terlalu banyak memerlukan C dan $\mathrm{N}$ organik. Dalam pertumbuhannya, bakteri ini memerlukan nutrisi makro $(\mathrm{H}, \mathrm{O}, \mathrm{C}, \mathrm{N}, \mathrm{P}, \mathrm{S}, \mathrm{K}, \mathrm{Mg}$,

Tabel 2. Komposisi air lindi TPA sampah di Leuwigajah (Setiyanto, dkk., 2012)

\begin{tabular}{cc}
\hline Elements & $(\%)$ \\
\hline $\mathrm{Ti}$ & 0.11 \\
$\mathrm{Al}$ & 5.13 \\
$\mathrm{Fe}$ & 1.97 \\
$\mathrm{Mn}$ & 0.0591 \\
$\mathrm{Ca}$ & 2.58 \\
$\mathrm{Mg}$ & 1.01 \\
$\mathrm{Zn}$ & 0.037 \\
$\mathrm{Ni}$ & 0.0174 \\
$\mathrm{Zr}$ & - \\
$\mathrm{Cs}$ & 0.112 \\
$\mathrm{Cu}$ & 0.024 \\
$\mathrm{As}$ & 0.416 \\
$\mathrm{Sr}$ & 0.0099 \\
$\mathrm{Cr}$ & 0.0093 \\
$\mathrm{Cl}$ & 10.21 \\
$\mathrm{Rb}$ & 0.0917 \\
$\mathrm{La}$ & 0.045 \\
$\mathrm{Eu}$ & 0.0123 \\
\hline
\end{tabular}


$\mathrm{Ca}, \mathrm{Na}$ ) dan nutrisi mikro (Fe, B, Cr, Co, Cu, Mn, Mo, $\mathrm{Ni}$, Se, W, V, Zn) (Madigan dkk., 2010). Oleh karena itu, air lindi yang digunakan ini dapat mempercepat pertumbuhan bakteri disebabkan air lindi tersebut mengandung unsur-unsur nutrisi makro dan mikro yang sangat diperlukan bagi pertumbuhan bakteri.

Pada penggunaan molase sebagai substrat, hasilnya kurang baik, diperkirakan karena bakteri sensitif terhadap kandungan $\mathrm{C}$ dan $\mathrm{N}$ yang terlalu tinggi dalam molase. Karena molase tidak mengandung mineral anorganik lain yang menjadi stimulator untuk pertumbuhan bakteri, bakteri tidak dapat tumbuh dengan optimal. Pada kondisi ini, bakteri tidak dapat menggenerasi produk metabolismenya berupa asam sulfat dan asam organik dengan baik sehingga substrat molase ini tidak menghasilkan penurunan $\mathrm{pH}$ yang signifikan dengan berjalannya waktu.

Persen ekstraksi nikel sebagai fungsi waktu pada pelindian dengan jenis substrat dan jumlah penambahan belerang yang berbeda untuk fraksi ukuran bijih $-60+80 \#$ ditunjukkan pada Gambar 3. Hasil percobaan menunjukkan kenaikan persen ekstraksi nikel hingga minggu ke-4 pelindian. Peningkatan persen ekstraksi nikel dengan berjalannya waktu pelindian ini sejalan dengan hasil pengukuran $\mathrm{pH}$ (Gambar 2) yang terus menurun terhadap waktu. Secara termodinamika, pelarutan nikel dapat berlangsung bila kondisi larutan cukup asam sehingga nikel stabil dalam bentuk ionnya. Nilai $\mathrm{pH}$ yang terus menurun dan persen ekstraksi nikel yang terus meningkat hingga 28 hari pelindian menunjukkan bahwa laju produksi asam lebih tinggi dibandingkan laju konsumsi asam untuk melarutkan nikel dan logam-logam lainnya dalam bijih seperti Fe dan Mg. Pada penggunaan substrat molase, persen ekstraksi $\mathrm{Ni}$ tertinggi diperoleh pada minggu ke-4 sebesar $28,3 \%$. Dengan durasi waktu pelindian yang sama, penambahan substrat air lindi menghasilkan persen esktraksi Ni yang lebih tinggi yaitu 34,3\%.

Persen ekstraksi Ni yang diperoleh belum tinggi karena metode yang digunakan adalah direct bioleaching dan konsentrasi asam yang dihasilkan oleh aktivitas bakteri belum mencapai level konsentrasi tertentu yang memadai untuk mencapai persen ekstraksi $\mathrm{Ni}$ $>90 \%$. Namun demikian, dengan kecenderungan $\mathrm{pH}$ yang terus menurun terhadap waktu, persen ekstraksi $\mathrm{Ni}$ akan terus meningkat bila waktu pelindian diperpanjang melebihi 28 hari dan ditambahkan bakteri serta media pertumbuhan bakteri yang baru.

Penelitian ini merupakan studi pendahuluan untuk mempelajari efektifitas bakteri mixotrof yaitu Ali- cyclobacillus ferrooxidans, Bacillus mucilaginosus dan Pseudomonas putida yang digunakan bersamasama dalam bioleaching $\mathrm{Ni}$ dari bijih nikel laterit. Pada tahap selanjutnya akan dilakukan optimalisasi proses bioleaching dengan menambahkan bakteri dan media yang baru setelah jangka waktu tertentu bioleaching dimulai. Selain itu, dengan telah diketahuinya bahwa bakteri mixotrof dapat digunakan untuk direct bioleaching nikel dari bijih laterit, selanjutnya dapat dilakukan biogenerasi asam secara terpisah sehingga asam yang digunakan untuk proses pelindian dapat diatur konsentrasi awalnya dan diperoleh persen ekstraksi Ni yang lebih tinggi (metode indirect bioleaching).

\section{Pengaruh Fraksi Ukuran Partikel Bijih}

Ukuran partikel bijih menentukan luas permukaan bijih yang akan terpapar pada larutan selama pelindian. Secara umum, semakin halus ukuran partikel bijih, semakin besar luas permukaan kontak antara bijih dengan larutan pelindi. Gambar 4-6 menunjukkan profil persen ekstraksi nikel terhadap waktu pelindian pada fraksi ukuran bijih dan persen penambahan belerang yang bervariasi. Persen ekstraksi nikel meningkat dengan berjalannya waktu pelindian dan pada distribusi ukuran partikel bijih yang semakin kasar, khususnya pada persentase belerang $20 \%$ dan $30 \%(\mathrm{w} / \mathrm{w})$.

Hasil yang diperoleh ini berbeda dengan kecenderungan umum pengaruh ukuran partikel bijih pada proses pelindian yaitu persen ekstraksi logam cenderung meningkat dengan semakin halusnya ukuran partikel bijih yang dilindi. Belum diketahui secara pasti mengapa pada fraksi ukuran bijih yang lebih halus persen ekstraksi nikel yang diperoleh lebih rendah. Hasil penelitian dari peneliti lain (Valix, dkk. 2001 dan Astuti 2011) menunjukkan bahwa dalam proses bioleaching, nikel terlarut dapat teradsorpsi oleh mineral pengganggu dan biomass yang digunakan dalam bioleaching. Pada ukuran partikel bijih yang lebih halus, luas permukaan mineral pengganggu dan biomass ini semakin besar sehingga cenderung menurunkan persen ekstraksi nikel pada fraksi ukuran yang lebih halus.

\section{Pengaruh Penambahan Belerang}

Bakteri mixotrof yang digunakan diprediksi memiliki kemampuan mengkatalisasi oksidasi belerang menjadi ion sulfat yang memberikan keasaman larutan pelindi. Oksidasi belerang menjadi ion sulfat diikuti oleh pelepasan ion $\mathrm{H}^{+}$oleh metabolisme bakteri. Konversi belerang menjadi asam sulfat dibuktikan 

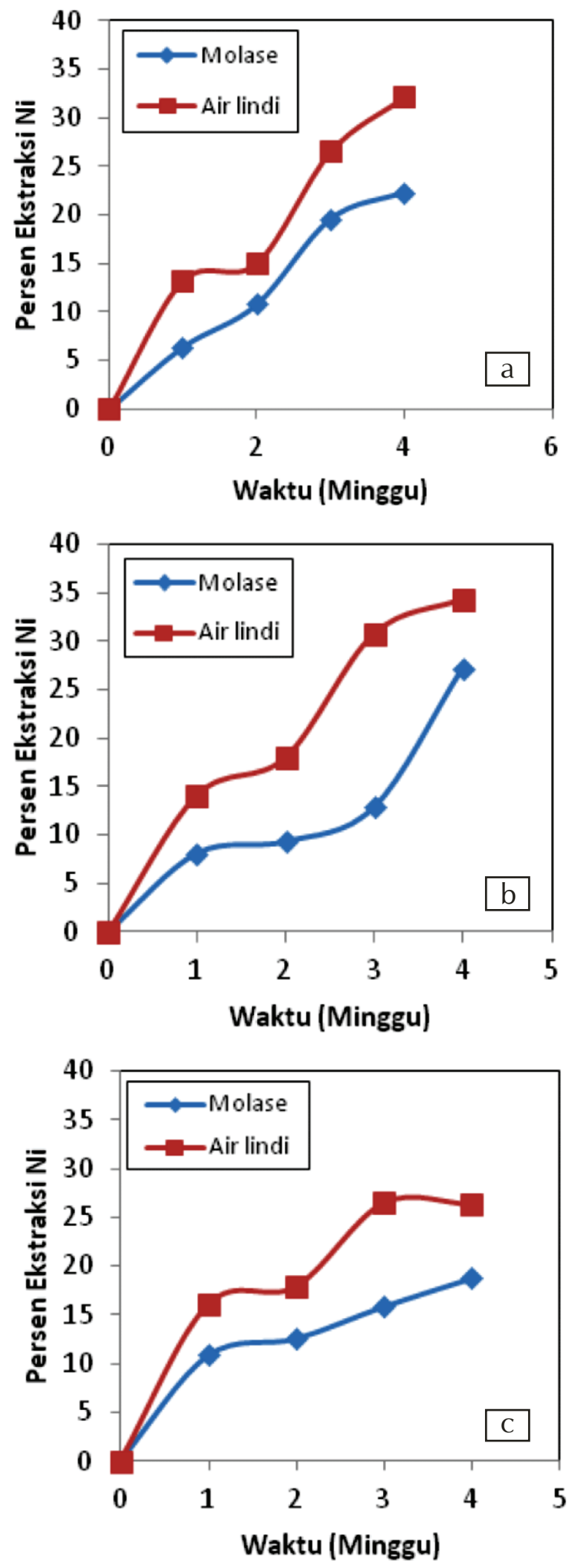

Gambar 3. Profil persen ekstraksi nikel terhadap waktu pada variasi jenis substrat organik, untuk bijih berukuran $-60+80$ mesh dan penambahan (a) $10 \%$ S (b) $20 \%$ S (c) $30 \%$ S

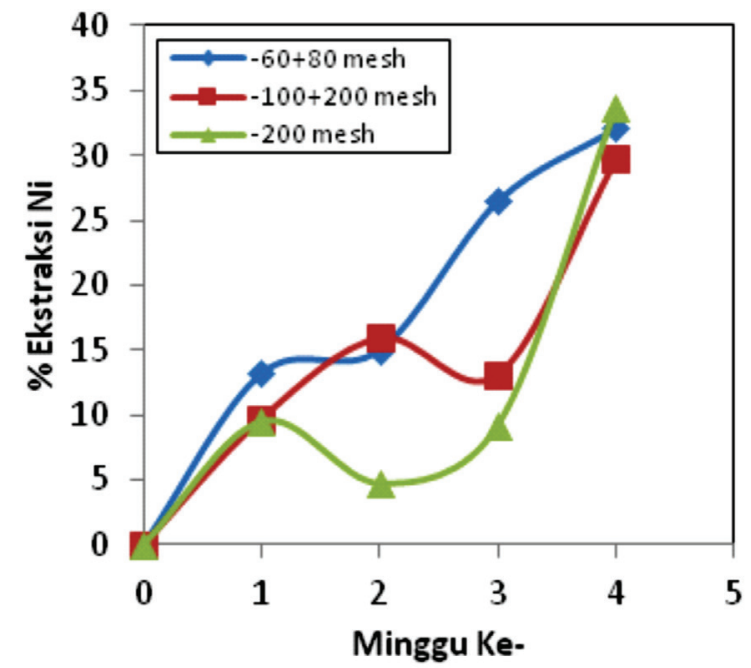

Gambar 4. Profil \%ekstraksi nikel terhadap waktu pada berbagai ukuran bijih, dengan penambahan air lindi dan $10 \% \mathrm{w} / \mathrm{w}$ belerang elemental

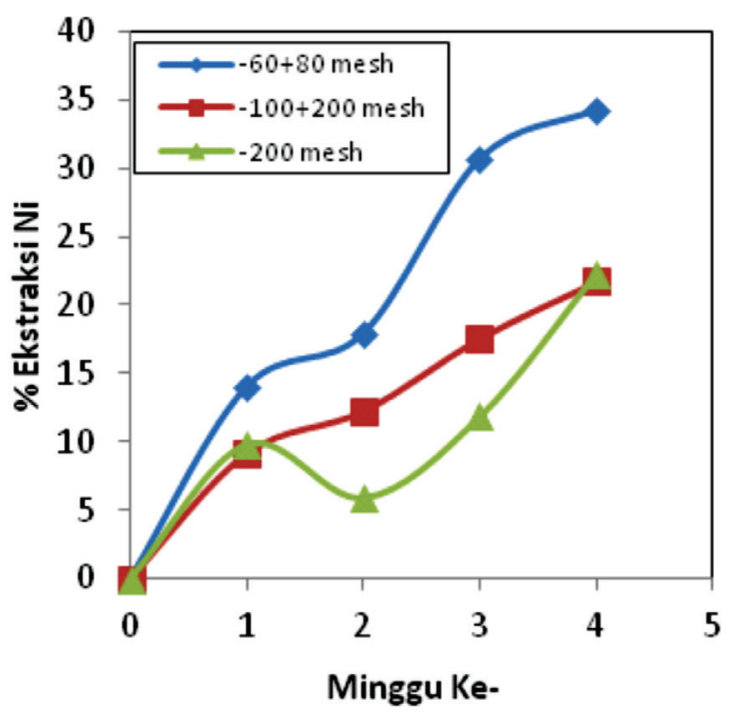

Gambar 5. Profil \% ekstraksi nikel terhadap waktu pada berbagai fraksi ukuran bijih, dengan penambahan air lindi dan $20 \%$ w/w unsur belerang

melalui pengukuran konsentrasi ion $\mathrm{SO}_{4}{ }^{2-}$ yang dilakukan dengan metode titrasi asam-basa. Proses terbentuknya asam sulfat membutuhkan oksigen dari udara yang dihasilkan dari proses agitasi selama proses bioleaching dalam rotating shaker, berdasarkan reaksi berikut (Rawlings, 2003):

$2 \mathrm{~S}^{\circ}+3 \mathrm{O}_{2}+2 \mathrm{H}_{2} \mathrm{O} \stackrel{\text { bakteri }}{\rightarrow} 2 \mathrm{H}_{2} \mathrm{SO}_{4}$ 


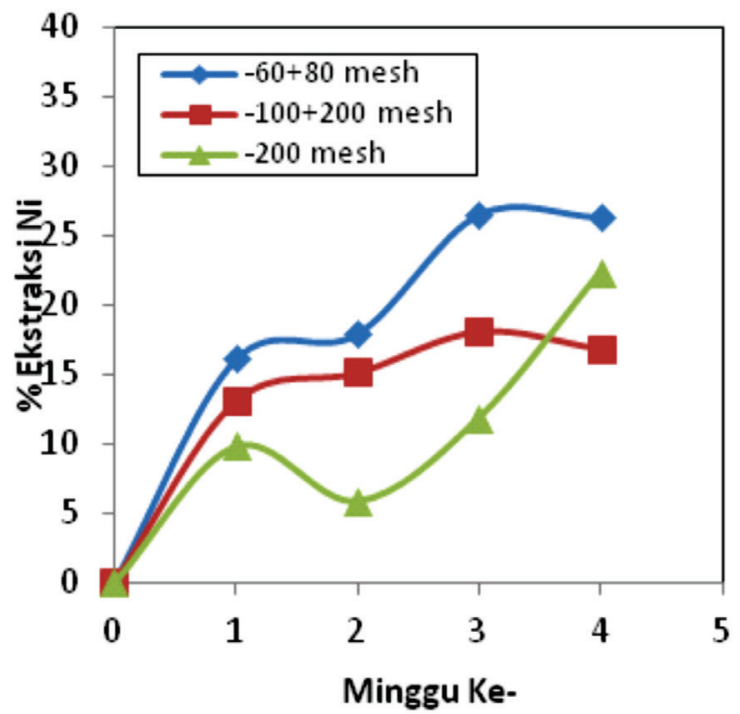

Gambar 6. Profil \% ekstraksi nikel terhadap waktu pada berbagai fraksi ukuran bijih, dengan penambahan air lindi dan $30 \% \mathrm{w} / \mathrm{w}$ unsur belerang

Penambahan belerang 10\%, 20\% dan 30\% dari berat bijih tidak memberikan perbedaan perubahan nilai $\mathrm{pH}$ yang signifikan baik pada media air lindi maupun molase. Gambar 7 menunjukkan profil perubahan $\mathrm{pH}$ sebagai fungsi waktu pada variasi penambahan unsur belerang untuk ukuran partikel -200 mesh dan sumber karbon organik berupa air lindi. Dapat dilihat pada Gambar 7 bahwa nilai $\mathrm{pH}$ masih cenderung turun apabila percobaan dilanjutkan lebih dari 28 hari.

Pengaruh penambahan belerang terhadap ekstraksi nikel ditunjukkan pada Gambar 8-10. Persen ekstraksi nikel tertinggi diperoleh pada percobaan dengan substrat air lindi dan fraksi ukuran bijih $-60+80$ mesh serta penambahan $20 \%$ belerang (Gambar 8). Jumlah belerang yang ditambahkan harus cukup memadai sehingga terbentuk asam sulfat yang cukup untuk pelindian. Namun demikian, jumlah belerang yang ditambahkan juga tidak boleh berlebih sehingga terdapat belerang sisa yang tidak teroksidasi dan menutupi permukaan bijih dan menghalangi kontak antara permukaan bijih dengan larutan sehingga bijih menjadi pasif. Analisis XRD pada residu mendeteksi keberadaan belerang untuk percontoh residu yang diambil setelah pelindian selesai seperti ditunjukkan pada Gambar 11 untuk percobaan dengan substrat air lindi, ukuran bijih $-60+80$ mesh dan penambahan $10 \%$ S yang mempunyai persen ekstraksi Ni paling rendah. Selain itu spektrum XRD residu mengindikasikan ada fraksi

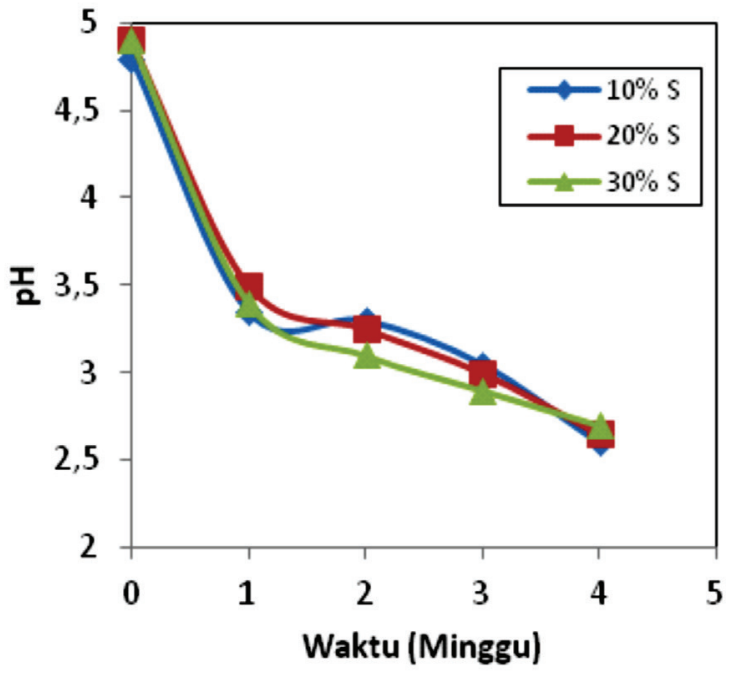

Gambar 7. Profil perubahan pH terhadap waktu pada variasi penambahan belerang untuk fraksi ukuran bijih -200 mesh dan air lindi sebagai sumber karbon organik

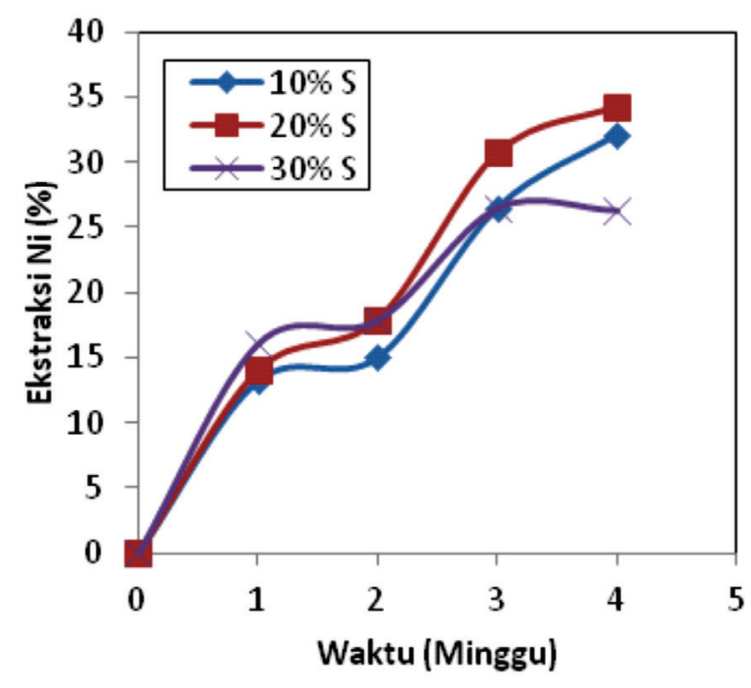

Gambar 8. Profil \% ekstraksi Ni terhadap waktu pada variasi penambahan S untuk fraksi ukuran bijih -60+80 mesh dan substrat organik air lindi

goethite $(\mathrm{FeOOH})$ yang belum larut.

\section{Selektivitas Pelindian}

Selektivitas pelindian menunjukkan efektivitas pelindian yaitu kemampuannya melarutkan logam berharga sebanyak mungkin dengan seminimal mungkin melarutkan logam-logam pengotor dalam 


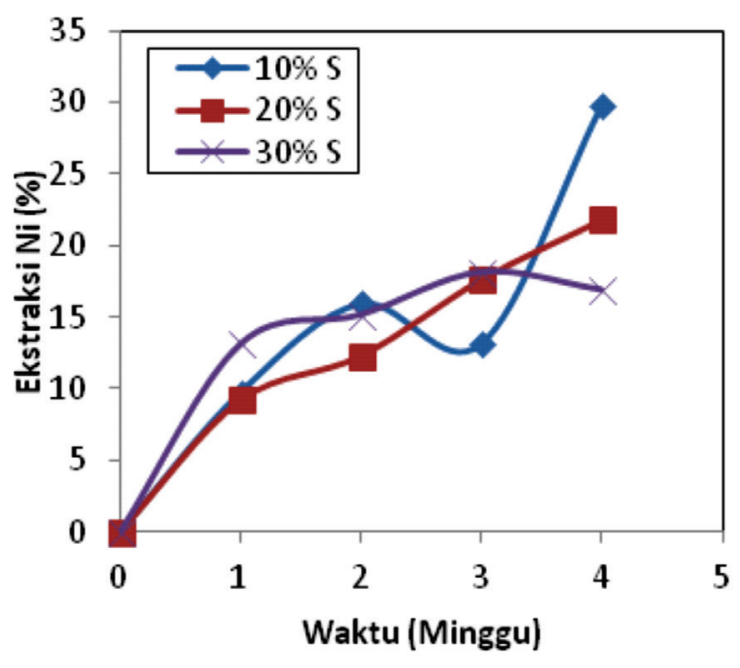

Gambar 9. Profil \% ekstraksi Ni terhadap waktu pada variasi penambahan $S$ untuk fraksi ukuran bijih -100+200 mesh dan substrat organik air lindi

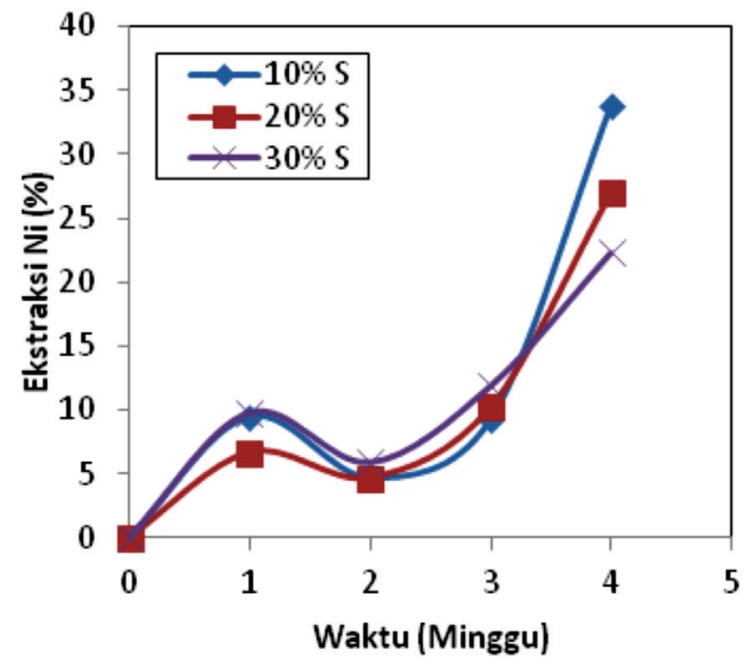

Gambar 10. Profil \% ekstraksi Ni terhadap waktu dengan variasi penambahan $S$ untuk ukuran partikel -200 mesh dan substrat organik air lindi

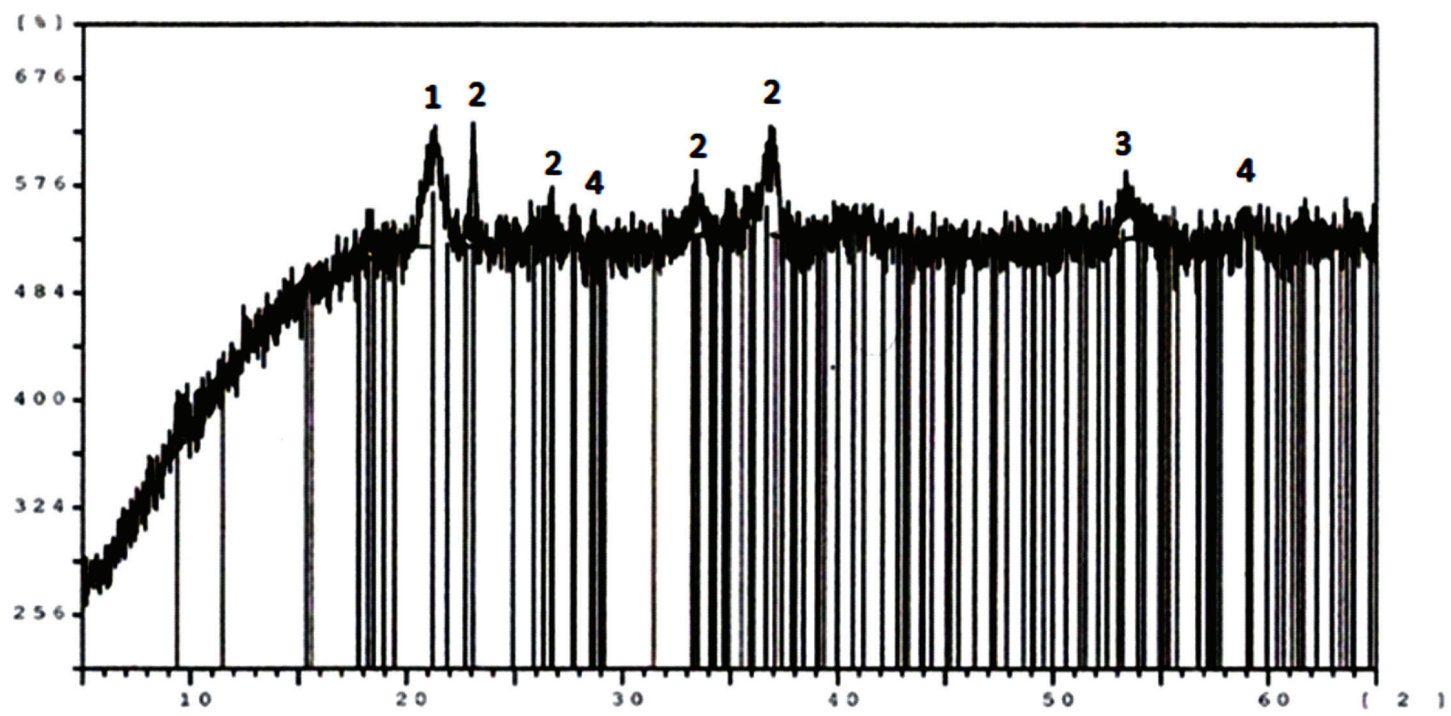

$\mathbf{z} \mathbf{Y}-2$

\section{Goethite (FeOOH) \\ 2. Sulfur (S) \\ 3. Magnesium-sulfate-Hydroxide $\left(\mathrm{Mg}_{1.33} \mathrm{SO}_{4}(\mathrm{OH})_{0.66}\right.$ \\ 4. Nickel-hydroxi-silicate $\left(\mathrm{Ni}_{3} \mathrm{Si}_{4} \mathrm{O}_{10}(\mathrm{OH})_{2}\right)$}

Gambar 11. Spektrum XRD residu hasil pelindian setelah 28 hari dengan substrat berupa air lindi, fraksi ukuran bijih $-60+80$ mesh dan penambahan $10 \%$ belerang

bijih. Selain oksida nikel, senyawa-senyawa lain dalam bijih nikel laterit tipe limonit yang mungkin terlarut dalam larutan asam terutama adalah oksida besi dan magnesium. Oksida-oksida pengotor yang ikut terlarut tersebut akan mengkonsumsi asam dan khususnya besi harus dipisahkan terlebih dahulu sebelum dilakukan recovery nikel baik sebagai produk antara seperti hidroksidanya atau sebagai nikel logam melalui electrowinning. Untuk tipe bijih limonit yang keberadaan nikelnya sebagian 
besar ada dalam "larutan padat" (solid solution) dengan goethite $(\alpha-\mathrm{FeOOH})$. Oleh karenanya, untuk melarutkan nikel sebagian besar besi dalam mineral goethite juga akan ikut terlarut. Selektivitas pelindian akan baik bila besi yang sudah terlarut dapat mengendap kembali. Pelarutan oksida nikel dan oksida serta hidroksida pengotor berlangsung melalui reaksi-reaksi berikut:

$$
\begin{aligned}
& \mathrm{NiO}+2 \mathrm{H}^{+}=\mathrm{Ni}^{2+}+\mathrm{H}_{2} \mathrm{O} \Delta \mathrm{Go}=-22,38 \mathrm{~kJ} / \\
& \mathrm{mol} \\
& \mathrm{FeOOH}+3 \mathrm{H}^{+}=\mathrm{Fe}^{3+}+2 \mathrm{H}_{2} \mathrm{O} \Delta \mathrm{Go}=-164,14 \\
& \mathrm{~kJ} / \mathrm{mol} \\
& \mathrm{MgO}+2 \mathrm{H}^{+}=\mathrm{Mg}_{2}+\mathrm{H}_{2} \mathrm{O} \quad \Delta \mathrm{Go}=-123,30 \\
& \mathrm{~kJ} / \mathrm{mol}
\end{aligned}
$$

Dalam kondisi asam, baik Fe, Ni maupun Mg stabil dalam bentuk ionnya seperti ditunjukkan oleh Diagram Pourbaix sistem Fe-Ni-Mg- $\mathrm{H}_{2} \mathrm{O}$. Oleh karena itu, bila oksida $\mathrm{NiO}, \mathrm{FeOOH}$ dan $\mathrm{MgO}$ terpapar dalam larutan asam, maka semuanya akan cenderung larut dan terkonversi oleh ionnya yang diindikasikan juga oleh harga $\Delta$ Go reaksi yang negatif. Pelindian akan bersifat selektif bila ionion tersebut dapat diendapkan kembali dan dalam

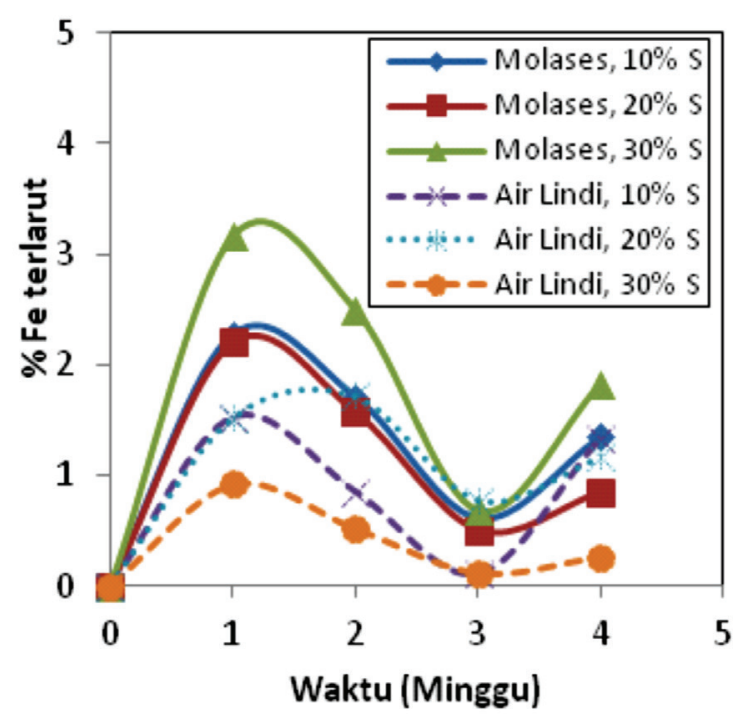

Gambar 12. Profil \%Fe terlarut terhadap waktu pada variasi jenis substrat dan jumlah penambahan belerang pada fraksi ukuran bijih $-60+80$ mesh proses pengendapan tersebut dilepaskan ion $\mathrm{H}^{+}$ (kebalikan dari reaksi-reaksi di atas).

Selektivitas bioleaching terhadap besi dan magnesium pada penelitian ini dipelajari pada jenis substrat dan jumlah penambahan belerang yang divariasikan. Profil Fe dan Mg terlarut sebagai fungsi waktu untuk substrat berupa air lindi dan molase pada persen penambahan belerang yang bervariasi dan fraksi ukuran bijih $-60+80$ mesh ditunjukkan masing-masing pada Gambar 12 dan 13. Hasil penelitian menunjukkan bahwa substrat air lindi memberikan selektivitas pelindian terhadap Fe dan Mg yang lebih baik dibandingkan molase.

Keterlarutan magnesium yang rendah karena terjadi pengendapan dan pembentukan senyawa kompleks magnesium sulfat hidroksida, seperti dikonfirmasi oleh hasil analisa XRD pada residu pelindian (Gambar 11). Berdasarkan analisis XRD terhadap bijih, diketahui magnesium yang terkandung dalam bijih berbentuk senyawa enstatite $((\mathrm{Mg}, \mathrm{Fe})$ $\mathrm{SiO}_{3}$ ) dan yang didapatkan dalam residu pelindian dalam bentuk magnesium-sulfate-hydroxide $\left(\left(\mathrm{Mg}_{1.33} \mathrm{SO}_{4}(\mathrm{OH})_{0.66}\right)\right.$.

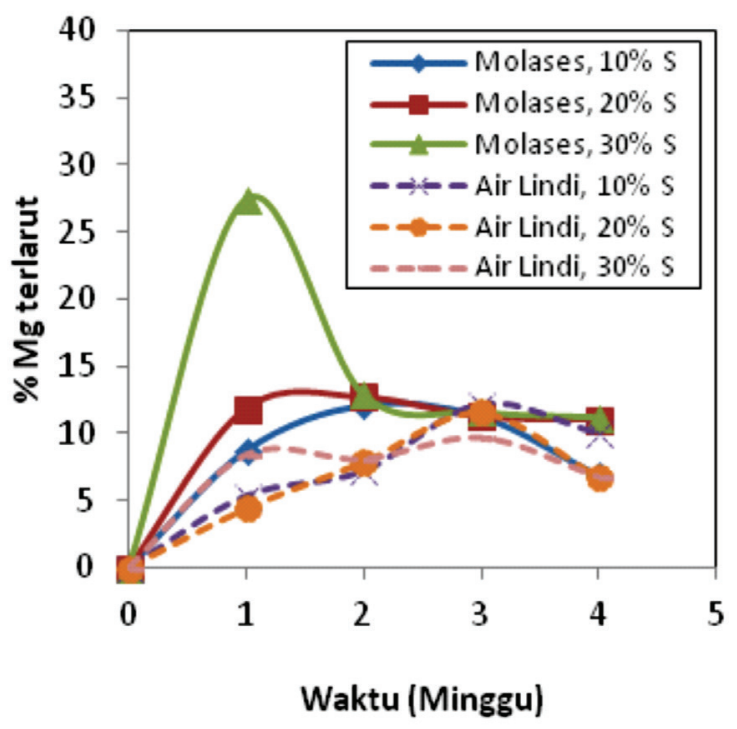

Gambar 13. Profil \%Mg terlarut terhadap waktu pada variasi jenis substrat dan jumlah penambahan belerang pada fraksi ukuran bijih $-60+80$ mesh 


\section{KESIMPULAN DAN SARAN}

Hasil percobaan menunjukkan bahwa konsorsium bakteri mixotrof Alicyclobacillus ferrooxidans, Bacillus mucilaginosus dan Pseudomonas putida yang diisolasi dari daerah pertambangan nikel di Soroako, Sulawesi Selatan dapat digunakan untuk pelindian bijih nikel laterit tipe limonit dari Pulau Gag. Persen ekstraksi nikel tertinggi setelah 28 hari adalah $34,30 \%$ dan masih cenderung meningkat bila waktu pelindian diperpanjang. Air lindi memberikan perubahan $\mathrm{pH}$ dan persen ekstraksi nikel yang lebih baik daripada molase sebagai substrat sumber karbon organik pada percobaan bioleaching yang dilakukan. Jumlah penambahan belerang sebanyak $20 \%$ dari berat bijih memberikan persen esktraksi nikel tertinggi dimana peningkatan jumlah belerang yang ditambahkan justru menurunkan persen ekstraksi nikel. Persen ekstraksi nikel paling tinggi diperoleh pada fraksi ukuran bijih $-60+80$ mesh. Air lindi juga memberikan selektivitas pelindian terhadap besi dan magnesium yang lebih baik daripada molase.

Beberapa hal dapat dilakukan untuk meningkatkan persen ekstraksi nikel yaitu melakukan penambahan bakteri yang baru (fresh) dan substrat air lindi setelah hari tertentu pelindian sehingga dapat digenerasi asam yang baru. Agar konsentrasi asam dapat dikontrol dengan baik, pelindian dapat dilakukan secara indirect bioleaching yaitu asam digenerasi secara terpisah oleh bakteri hingga diperoleh konsentrasi tertentu yang kemudian digunakan untuk pelindian pada reaktor yang terpisah.

\section{UCAPAN TERIMA KASIH}

Penulis berterima kasih kepada PT. Antam Tbk. yang telah menyediakan percontoh bijih nikel laterit dan mendanai penelitian ini.

\section{DAFTAR PUSTAKA}

Alting, S.A. 2010. Isolasi dan karakterisasi bakteri pengoksidasi besi dari bioleaching logam bijih mineral sulfida dan oksida, Tugas Akhir Sarjana, Institut Teknologi Bandung.

Astuti, W., 2011. Ekstraksi nikel dari bijih nikel laterit Pomalaa dengan metode bioleaching menggunakan konsorsium jamur Penicillium verroculosum dan Galactomyces geotrichum, Tesis Magister, Institut Teknologi Bandung.
Dalvi, D.A., Bacon, W.G. and Osborne, R.C., 2004. Past and the future of nickel laterites, PDAC International Convention, pp. 1-27.

Jain, N and Sharma, D.K., 2004. Biohydrometallurgy for nonsulfidic minerals: A Review, Geomicrobiology Journal, pp. 134-144.

Madigan, M.T., Martinko, J.M., Stahl, D.A., and Clark, D.P., 2010. Brock Biology of Microoganisms, Benjamin Cummings Publisher, 13th edition, p. 86-92.

Olbrich, H., 2006. The molases, Biotechnologie-Kempe $\mathrm{GmbH}$, p. 8-31.

Rawlings D.E., Dew D. and Du Plessıs, C., 2003, Biomineralization of metal-containing ores and concentrates. Tends in Biotechnology, Vol. I, pp. 38-44.

Robinson, H. 2007. The composition of leachates from very large landfils: An international review, Commission on Water Resource Management vol. 8, no. 1, p. 19-32.

Setiyanto, H., Simbolon, I.B.L., Rifka, Zulfikar, M.A., Amran, M.B. and Buchari, B., 2012. Comparative study on leachate in old and new municipal solid waste landfills at Bandung-Indonesia: Multielement minerals and other analysis. European Journal of Scientific Research, Vol. 79, no. 2 , pp. 159-165.

Simate, G.S., 2009. Bacterial leaching of nickel laterites using chemolithotrophic microorganisms, Dissertation, University of Witwaterstrand, South Africa, p. 15-19.

Sutina, 2010. Isolasi dan analisis filogenetika molekuler bakteri pengoksidasi belerang untuk bioleaching nikel pada bijih mineral laterit, Tugas Akhir Sarjana, Institut Teknologi Bandung.

Tang, L.L.J., Ryan, D. and Valix, M., 2006. Bioleaching nickel laterite ores using multi-metal tolerant Aspergillus foetidus organism. Minerals Engineering, Vol. 19, pp. $1259-1265$.

Valix, M, Usai, F. and Malik, R., 2001. The electrosorption properties of nickel on laterite gangue leached with an organic chelating acid. Minerals Engineering, Vol. 14, No. 2, pp. 205-215. 
